\title{
DIDACTIC POSSIBILITIES OF REALISATION OF INTERDISCIPLINARY RELATIONS: SUBJECT FRUIT JUICE PROPERTY
}

\author{
Violeta Šlekienè, Loreta Ragulienè, \\ Vincentas Lamanauskas \\ Siauliai University, Natural Science Education Research \\ Centre, Lithuania
}

\begin{abstract}
Annotation
Natural Science Education improvement remains one of the most important current challenges in education system. In general, 21 st century raises new challenges for Natural science, Mathematics, Technology teachers. Young generation interest in Natural Sciences and Technology is poor. It is predicted that in not so far future, a shortage of qualified specialists will be felt in this sphere. It is obvious, that Natural science and Technology education basics is being formed in general education school. How to strengthen the pupils'Natural science and Technology learning motivation, to increase their interest? This is one of the most important questions of today's education. On the other hand, improvement has to be carried out in different directions. Not only motivation strengthening is important, but also creating proper educational environments (spoken here about green environment, so-called outdoor didactics, teacher competence and so on). Extra didactic material preparation for teachers becomes an urgent question. It is very important to help teachers prepare for practical work lessons and to give them, using ordinary and digital devices for the performance of practical-experimental works.
\end{abstract}

In this analysis, a didactic scenario is presented realising an interdisciplinary integral teaching/learning. The investigated topic is "Juice properties". Natural sciences and Mathematics teachers' collaboration possibilities are revealed.

Key words: interdisciplinary relations, natural science education, titration, vitamin $C$.

\section{Introduction}

One of the most important aims of Natural science education is integral perception of biological, chemical, physical processes and phenomena, occurring in nature. Therefore, the main task of the teachers is to be able to find connection between separate natural sciences and manage to convey the perceived entire natural science understanding to the pupils during the research work. Mathematics is also closely integrated with Natural sciences, because learning all these subjects, mathematical competencies are necessary. In Lithuanian general education school General Programmes (Primary and general education..., 2008a; Primary and general education ...., 2008b; Secondary education general...., 2011), defining educational content of Natural sciences and Mathematics, interdisciplinary relationship development importance is accentuated.

The pupil, learning Natural sciences, has to create for himself a unanimous, not divided into separate disciplines, worldview. Therefore, natural sciences has to be taught as an integrated subject, examining real animate and inanimate nature phenomena and objects. Interdisciplinary natural science education relations are developed mostly among Biology, Chemistry, Physics, Mathematics and Information Technologies. The teachers have to convey educational content, containing separate concepts, laws and theories as 
a sustainable wholeness, revealing the interrelationship of the examined phenomena. Organising Natural science teaching in this way, the teaching material is reorganized, systemised. Solving interdisciplinary integration problems, active communication and collaboration among separate Natural science subject teachers takes place.

It is impossible to systemise pupils' knowledge without interdisciplinary relationship, therefore, such teaching forms people so that they acquire a lot of theoretical material however, they cannot apply this material in practical activities. Interdisciplinary relationship, as a didactic condition, helps to form pupils' worldview and plays an important role, developing their creative abilities. For the teacher and even more for the pupil, it is not easy to perceive a tremendous amount of acquired knowledge and abilities at school, to find relations between related knowledge, abilities and to join them into unanimous system. The acquired knowledge systematization, ability formation are complicated processes. For Natural Science and Mathematics knowledge system formation, it is important, that the knowledge acquired at a certain teaching stage was consolidated interrelating it. Favourable conditions are formed for this, generalising, revising Natural science and Mathematics separate elements and using them in a concrete lesson, performing integrated tasks.

Solving interdisciplinary integration problems, active communication and collaboration between individual Natural science teachers has to take place. Educators who help students develop their confidence and ability in mathematics and science would have a positive impact on students' lives in the long term (Furner, Kumar, 2007).

Interdisciplinary integration realisation cannot go itself. The research results showed, that students accentuate the importance of integration relationship application, making the pupils interested in Natural science subjects, helping educate the abilities to apply the knowledge practically, however, they feel professional and methodical preparation shortage to apply Natural science integration in practical work (Cibulskaite, 2015).

For the realization of interdisciplinary integration, it is necessary to specially organise teaching process itself, to prepare teaching material. First of all, it is necessary to single out the material which reflects interdisciplinary relations, to select teaching forms, methods and ways. For such material preparation, teacher collaboration is necessary. In other words, these are the results of their collaborative work together in the creation of interdisciplinary units connecting mathematics and science topics (Frykholm, Glasson, 2005).

Interdisciplinary relations in the teaching process are inter-science relation didactic equivalent. Pupils have to understand, what unites and what separates Natural sciences and Mathematics. Using mathematical methods, it is convenient to analyze and describe natural phenomena. Mathematics enables closely and accurately describe test results, to evaluate biases. One of Mathematics and Natural science relation elements is functional dependencies. In Natural sciences it is always recollected, that symbols and formulas used in Mathematics must have the meaning, that they describe the real world, whilst Mathematics examines relations among abstract objects, without a concern if they find a place in the world. This is the essential difference of these sciences.

Interdisciplinary Natural Science and Mathematics relations have been analysed by the article authors, examining also the other Natural Science topics: Nanotechnology beginning - fullerenes (Šlekienè, Ragulienè, Lamanauskas, 2015a), Water salinity (Šlekienè, Ragulienè, Lamanauskas, 2015b).

The aim of analysis: to discover Natural Science and Mathematics relation realisation didactic possibilities, analysing different juice properties. 


\section{Lessons organization and methodology of research performance}

During this lesson the experiment is carry out: vitamin C concentration in fruit juices of different types and different brands is investigated.

At the beginning of lesson students are asked about vitamin meaning in everyday nutrition, about significance of vitamins and minerals, what vitamin $\mathrm{C}$ sources they know.

Pupils are asked to recall from mathematics: fractions (proportions), percent calculation, to recollect error calculation. It is appropriate to repeat the basic feature of proportions (Figure 1), because, when solving the Science problems, noted that the students hardly perform operations with fractions, especially when instead of numerical values of science quantities, in the problem presented their letter designation.

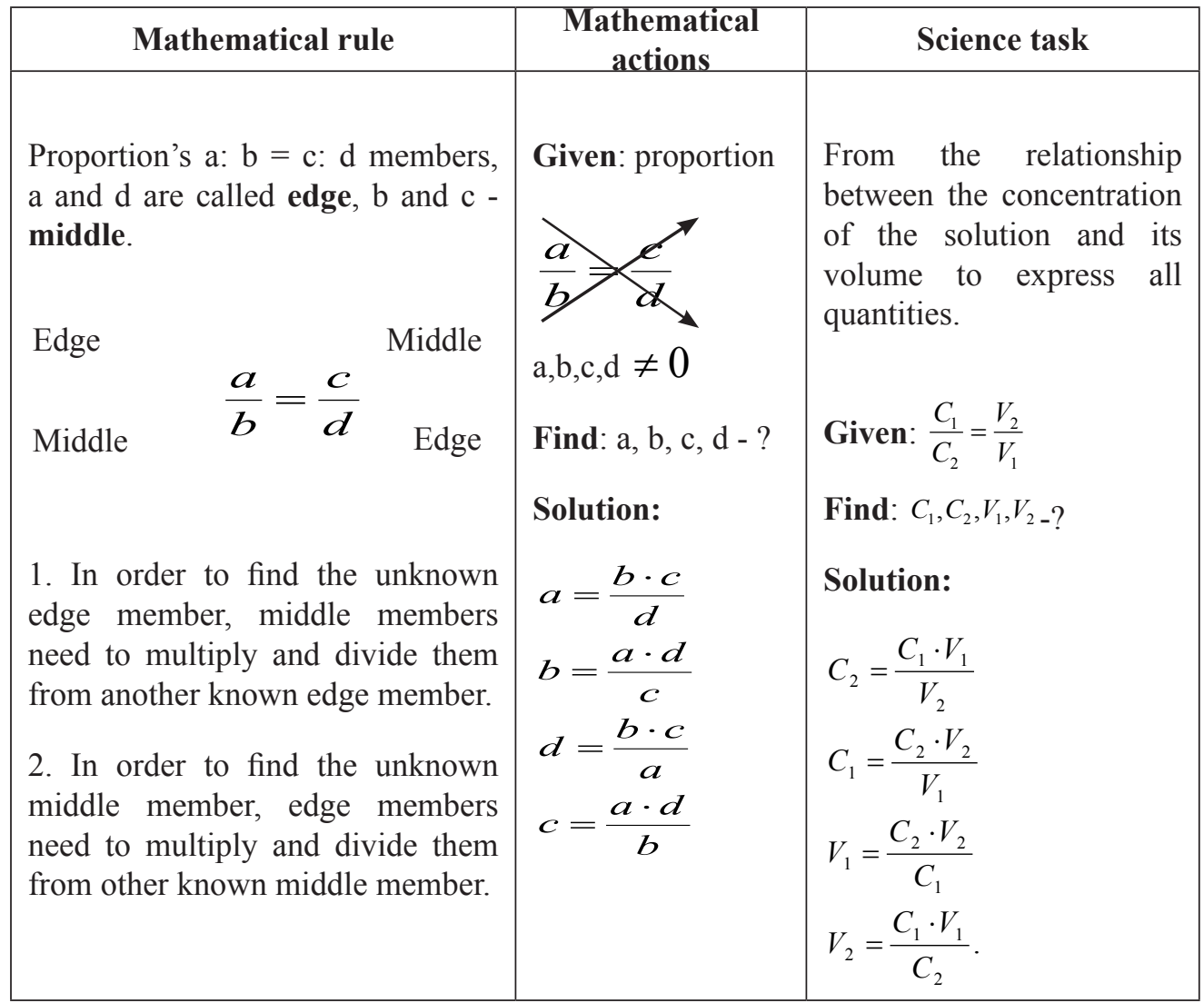

Figure 1: The relationship between science and mathematics when applicable the basic feature of the proportions.

Students are presented with a consistent workflow and with a list of equipment needed for this activity. As the results of this work among students are not known in advance, the possibility of discussion in groups arises. Analysis of results and discussion effective when the work is done in groups of 2-3 students. In case class does not contain the necessary equipment and reagents, the teacher demonstrates researched juice titration.

With the more gifted pupils the question is discussed, in what capacity of one or 
another juice is the day norm of vitamin C. Students who complete the work quickly are asked to work on the extension tasks provided.

Expected Learning outcomes for this activity:

All students

- Will understand vitamin meaning in everyday nutrition.

- Will be able to arrange the instruments for work according to instruction.

- Will be able to apply iodometric titration method.

Most students

- Will be able to calculate molar concentration of the solution.

- Will be able to calculate vitamin $\mathrm{C}$ concentration in juice.

Some students

- Will be able to calculate the mean square error of the measurements.

- Will be able to calculate titration error.

- Will be able to evaluate the result accuracy.

Structural parts of the lesson:

- discussion of theoretical material,

- explanation of the practical work,

- performance of the experiment and tasks,

- discussion of the results and their significance.

\section{Vitamin $\mathrm{C}$ concentration ascertainment}

Fruit and vegetable juice is produced from ripe fruit, berries and vegetables squeezing them for extraction. The most valuable part of the juice is the pulp, because all cellulose fibres get into it, for example, tomato, carrot, sea buckthorn, apricot, plum. Produced juice is used fresh, you do not have to boil it, preserve or pasteurize, otherwise all ferments and a part of vitamins will be destroyed. Juice with sugar is of less value. In a lot of juice, there are vitamin $\mathrm{C}$, potassium, calcium ions, and in very small amounts of iron, copper, manganese, cobalt, zinc, nickel ions, necessary for the body.

Fruit drinks have up to $30 \%$ of fruit juice; e.g., in grape drink there is $6 \%$, lemon about $10 \%$ of juice. These drinks are very widespread, because they are cheaper.

The cellulose fibre, being the major structural component in vegetables and fruit, influences fat circulation, decreases the level of cholesterol in blood, helps to remove poisonous materials from our body. Potassium - regulates the transmission of nerve impulse, muscle activity, water balance in the cells. A day potassium dose is $2000 \mathrm{mg}$. Potassium is the major compound of bone and teeth mass. There body stores about $98 \%$ of potassium in human cells, for example Potassium citrate helps strengthen bones. Potassium, which is not in the bone tissues, plays a great role transmitting nerve impulse for ribs and heart muscle fibres. This part of potassium is important for coagulation systems, fermentation reaction regulation. A day potassium dose is $800 \mathrm{mg}$.

Vitamin $\mathrm{C}$, ascorbic acid (C6H8O6), is one of the most unstable water-soluble vitamins. Reacting with oxygen, it quickly oxidizes, it is unstable for the influence of 
temperature, therefore thermally processed, the juice decomposes. The cells of almost all mammals can synthesize vitamin $\mathrm{C}$, unfortunately, human cells do not possess this feature therefore, its demand is satisfied, eating food of plant origin. Vitamin $C$ is in all organism liquids and cells, however, it is not stored in the organism, and the excess is excluded with urine. Vitamin $\mathrm{C}$ is also important as co ferment and as an antioxidant, takes part in collagen synthesis, the adrenal cortex, steroid hormone and other hormone synthesis. Vitamin C deficiency results in scurvy, increasing blood vessel fragility, occurring bone tissue changes, teeth becoming loose and falling out; developing heart function failure, anaemia.

A day dose of vitamin $\mathrm{C}$ is $75-100 \mathrm{mg}$. Since the human body is not synthesize vitamin $\mathrm{C}$, it has to be ingested from vegetables, fruit or berries.

Vitamin $\mathrm{C}$ concentration can be determined by iodometric titration method, carrying out its oxidation with iodine solution.

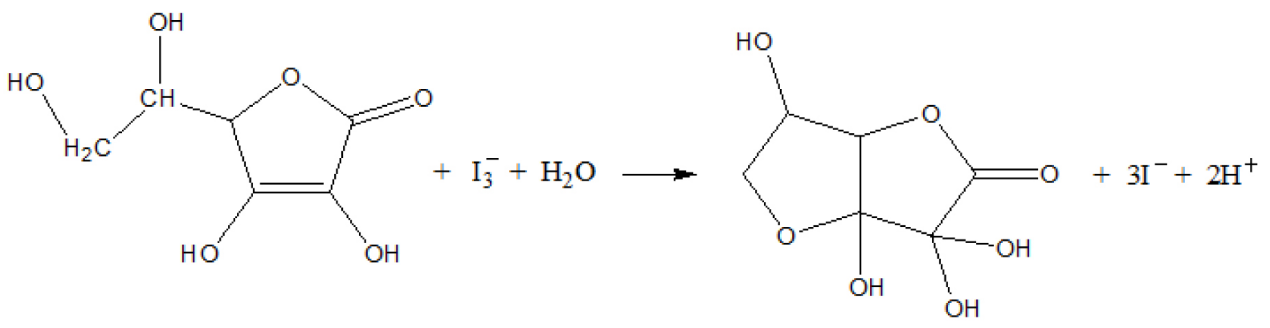

Ascorbic acid

Dehydroascorbic acid

Molecular iodine dissolves in water very weakly (only a $1,3 \times 10^{-3} \mathrm{M}$ at $20^{\circ} \mathrm{C}$ temperature), however, when it bound to the iodide ion, dissolves significantly better.

$$
\mathrm{I}_{2}(a q)+\mathrm{I}^{-} \rightleftharpoons \mathrm{I}_{3}^{-} \quad \mathrm{K}=7 \times 10^{2} .
$$

$0,05 \mathrm{M} \mathrm{I}_{3}{ }^{-}$solution is usually prepared dissolving $0,12 \mathrm{~mol} \mathrm{KI}$ and $0,05 \mathrm{~mol} \mathrm{I}_{2}$ in one litre of water.

Performing the titration with iodine solution, starch is used as an indicator. If there are no other colour combinations in iodine solution, one can still see the iodine colour at a concentration of at least $\sim 5 \mu \mathrm{M}$. Performing the titration with the starch, determination limit widens almost ten times.

Carrying out the titration with $\mathrm{I}_{3}^{-}$, starch is added at the beginning of the titration. Having reached the equivalence point the first excess $\mathrm{I}_{3}^{-}$drop turns the solution dark blue. Iodine and starch complex formation return reaction depends on temperature. Raising solution temperature from $25^{\circ} \mathrm{C}$ to $50^{\circ} \mathrm{C}$, colour intensiveness decreases ten times. In order to reach the biggest sensitiveness, it is recommended to chill the titrated solution in ice water.

Standard $\mathrm{I}_{3}^{-}$solution is made dissolving solid $\mathrm{I}_{2}$ in a significantly bigger concentration KI solution (to be an $\mathrm{I}^{-}$excess). For making standard solution, sublime $\mathrm{I}_{2}$ is that suits. As, in the process of weighing, the iodine evaporates a little, it has to be standardised by $\mathrm{Na}_{2} \mathrm{~S}_{2} \mathrm{O}_{3}$ solution.

The solution is comprised of a solvent and a dissolved substance (solute). One of the main characteristics of a solution is its concentration. Solution concentration shows the dissolved substance mass and quantity, existing in a certain mass or capacity of a solution or a solvent. 
Molar concentration shows, how many moles of the solute are dissolved in one litre of solution:

$$
C_{\mathrm{M}}=\frac{n}{V}, \mathrm{~mol} / \ell
$$

Where $n$ is the number of moles of the solute; $V$ - solute volume in litres.

Or

$$
C_{M}=\frac{m_{1}}{M \cdot V}, \mathrm{~mol} / \ell
$$

where $m_{1}$ is solute mass; $M$ is solute mole mass; $V$ is solute volume.

Instead of measurement unit $\mathrm{mol} / \ell$ often one letter $\mathrm{M}$ is written. Solutions, in one litre of which there is 0,$1 ; 0,01$ moles of substance, are correspondingly called decimoles and centimoles. $1 \mathrm{mg} / \ell$.

To describe solution concentration ppm units are used - parts per million. $1 \mathrm{ppm}=$

Often, from concentrated solutions one has to make solutions of smaller concentration. In such cases, it is very comfortable to use dilution rule:

$$
C_{1} \cdot V_{1}=C_{2} \cdot V_{2}
$$

Where $C_{1}$ and $V_{1}$ - molar concentration and capacity of concentrated solution;

$C_{2}$ and $V_{2}$ - molar concentration and capacity of dilute solution.

If solution concentrations are expressed in parts per mass, for calculation such formula is used, then:

$$
C_{1} \cdot V_{1} \cdot \rho_{1}=C_{2} \cdot V_{2} \cdot \rho_{2},
$$

Where $C_{1}, V_{1}, r_{1}$ - concentration, capacity and density of a concentrated solution;

$C_{2}, V_{2}, r_{2}$ - concentration, capacity and density of dilute solution.

\section{The essence of practical work and stages of experiment}

An explanation of practical is given.

The research problem. How vitamin $\mathrm{C}$ content in the juice depends on the juice type and brands.

The research hypothesis:

- Vitamin $\mathrm{C}$ is more in freshly squeezed juice than in juice from the trade network.

- Vitamin $\mathrm{C}$ in orange juice is more than in apple juice.

Equipment needed for this activity (Figure 2):

- scales;

- burette with a holder;

- $250 \mathrm{ml}$ measurement flask; 
- conical flasks for titration;

- chemical glasses;

- pipettes;

- washing dish with distilled water;

- Textbooks;

- Activity sheet.

Reagents:

- $0,01 \mathrm{M} \mathrm{I}_{3}^{-}$solution $\left(0,63 \mathrm{~g} \mathrm{I}_{2}\right.$ and $1,00 \mathrm{~g} \mathrm{KJ}$ is dissolved in approximately 200 $\mathrm{ml}$ of distilled water, poured into $250 \mathrm{ml}$ measurement flask and diluted up to the mark .)

- $1 \%$ starch solution.

- Fruit juice, squeezed by hands or from trade.

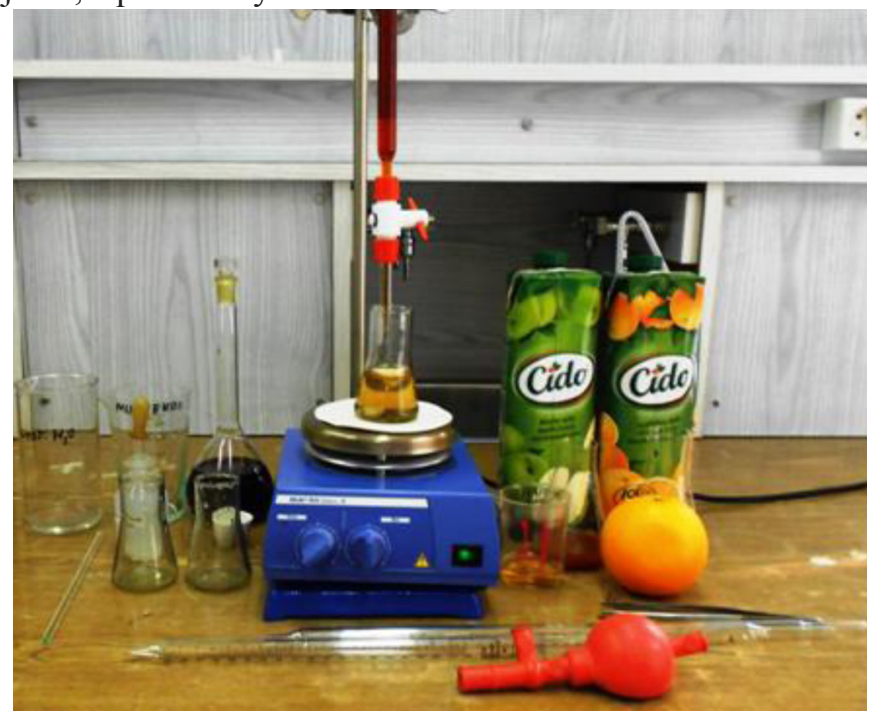

Figure 2: Equipment and reagents.

\section{Main Activity}

Pupils begin work on Ascertainment of Vitamin C concentration in fruit juice.

Students in groups of 2-3 carry out juice titration:

- Burette is washed twice with iodine solution and filled again up to $25 \mathrm{ml}$ capacity;

- $20 \mathrm{ml}$ of prepared juice is poured into a conical flask;

- $20 \mathrm{ml}$ of distilled water is poured with a pipette;

- 5 drops of $3 \mathrm{M} \mathrm{HCl}$;

- 10 drops of starch solution;

- The iodine solution is dripped from the burette until blue colour occurs, not vanishing for at least 20 seconds;

- During the titration, the solution is stirred with the magnetic stirrer or by hand;

- The titrated iodine solution capacity is measured;

- Titration is repeated three times;

- All juice samples are titrated in this way. 


\section{Completion of the tasks}

Pupils are asked to complete the activity work sheets individually, pupils are asked to record results, to fill in data table (Table 1), according to equivalence law, to calculate vitamin $\mathrm{C}$ concentration (Table 2), to compare vitamin $\mathrm{C}$ concentration in different fruit juice.

Table 1. Fruit juice titration data (Solution volume of titrated iodine)

\begin{tabular}{|l|c|c|c|c|}
\hline \multicolumn{1}{|c|}{$\mathbf{J u i c e}$ title } & $\begin{array}{c}\text { I titration, } \\
\boldsymbol{V}_{\mathbf{I}}, \mathbf{m} \boldsymbol{\ell}\end{array}$ & $\begin{array}{c}\text { II titration, } \\
\boldsymbol{V}_{\mathbf{I I}}, \mathbf{m} \boldsymbol{\ell}\end{array}$ & $\begin{array}{c}\text { III titration, } \\
\boldsymbol{V}_{\mathbf{I I I}}, \mathbf{m} \boldsymbol{\ell}\end{array}$ & $\begin{array}{c}\text { Mean value, } \\
\bar{V} \overline{\boldsymbol{V}}, \mathbf{m} \boldsymbol{\ell}\end{array}$ \\
\hline $\begin{array}{l}\text { Orange, } \\
\text { freshly squeezed }\end{array}$ & 7,2 & 7,4 & 7,3 & $7,3 \pm 0,1$ \\
\hline $\begin{array}{l}\text { Orange, } \\
\text { CIDO }\end{array}$ & 5,5 & 5,5 & 5,4 & $5,5 \pm 0,1$ \\
\hline $\begin{array}{l}\text { Apple, } \\
\text { freshly squeezed }\end{array}$ & 3,0 & 3,1 & 3,0 & $3,0 \pm 0,1$ \\
\hline $\begin{array}{l}\text { Apple, } \\
\text { CIDO }\end{array}$ & 1,0 & 0,85 & 1,0 & $1,0 \pm 0,1$ \\
\hline
\end{tabular}

Titration was carried out using a burette that systematic error $\mathrm{P}(\mathrm{sys})=0,1 \mathrm{ml}$.

Vitamin $C$ concentration is calculated according to equivalence law, expressed in $\mathrm{mol} / \ell$.

$$
V_{1} \times C_{1}=V_{2} \times C_{2}
$$

Where: $V_{1}$ - solution volume of titrated iodine, $V_{2}$ - volume of juice, taken for titration, $C_{1}$ - molar concentration of iodine solution, $C_{2}-$ vitamin $\mathrm{C}$ molar concentration in juice.

$$
C_{2}=\frac{V_{1} \times C_{1}}{V_{2}}
$$

Vitamin $\mathrm{C}$ concentration, calculated according to equivalence law, expressed in $\mathrm{mol} / \ell$. The units used in food industry are $-\mathrm{mg} / 100 \mathrm{~m} \ell$.

Recalculate vitamin C concentration in units used in food industry $\mathrm{mg} / 100 \mathrm{~m} \ell$ juice.

Calculation results is presented in table 2. 
Table 2. Vitamin C concentration in fruit juice

\begin{tabular}{|c|c|}
\hline Fruit juice title & Vitamin C concentration, $\mathbf{m g} / \mathbf{1 0 0} \mathbf{~ m} \boldsymbol{\ell}$ \\
\hline $\begin{array}{c}\text { Orange, } \\
\text { freshly squeezed }\end{array}$ & 64,3 \\
\hline $\begin{array}{c}\text { Orange, } \\
\text { CIDO }\end{array}$ & 48 \\
\hline $\begin{array}{c}\text { Apple, } \\
\text { freshly squeezed }\end{array}$ & 26,4 \\
\hline $\begin{array}{c}\text { Apple, } \\
\text { CIDO }\end{array}$ & 8,8 \\
\hline
\end{tabular}

Plenary

After discussion of the results students are asked to

- $\quad$ Compare vitamin $\mathrm{C}$ concentration in different fruit juice.

- Compare vitamin $\mathrm{C}$ concentration in freshly squeezed juice and in juice from shops.

- Ascertain, how much of each fruit juice is needed to give the daily recommended intake.

- How do experimental results correlate with the results presented in the literature (labels)?

Students are asked to make a conclusion about vitamin C concentration in different fruit juice. With the more gifted pupils the question is discussed, in what capacity of one or another juice is the day norm of vitamin $\mathrm{C}$.

\section{Extension activity}

Pupils who complete the work quickly are asked to work on the extension tasks provided.

\section{Calcium ion $\mathrm{Ca}^{2+}$ concentration in various fruit juice}

In chemistry lesson, the pupils investigated Calcium ion $\mathrm{Ca}^{2+}$ concentration in various fruit juice. Calcium ion concentration in solution was calculated in ppm (parts per million) units. The results of the experiment are given in table 3 . It is accepted to express concentration in nutrient substances in $\mathrm{mg} / 100 \mathrm{~m} \ell$. Fill in the table, having calculated $\mathrm{Ca}^{2+}$ concentration in $\mathrm{mg} / 100 \mathrm{~m} \ell$ of juice. It is known, that $1 \mathrm{ppm}=1 \mathrm{mg} / \ell$. 
Table 3. The results of the experiment

\begin{tabular}{|l|c|l|}
\hline \multicolumn{1}{|c|}{ Fruit name } & $\begin{array}{c}\mathbf{C a}^{2+} \text { concentration in } \\
\text { juice, } \mathbf{p p m}\end{array}$ & $\begin{array}{c}\mathbf{C a}^{2+} \text { concentration in } \\
\text { juice, } \mathbf{~ m g / 1 0 0 ~} \mathbf{~} \boldsymbol{\ell}\end{array}$ \\
\hline Freshly squeezed orange & 44 & \\
\hline CIDO orange & 34,8 & \\
\hline Freshly squeezed apple & 23,6 & \\
\hline ELMENHORSTER apple & 25,6 & \\
\hline
\end{tabular}

- Compare calcium ion concentration in freshly squeezed juice and in juice from shops.

- Estimate, how much one or another juice one has to drink, that it contained the day norm of $\mathrm{Ca}^{2+}$.

\section{Summing-up}

Seeking to implement one of the most important Natural science Education aims subject integrity, the teachers have to be able to discover and to convey to the pupils the connection between separate Natural Sciences. It is necessary to specially organise teaching material and the teaching process itself for this.

First of all, it is necessary to discern the material, which reflects interdisciplinary relations, to select teaching forms, methods and ways. The teacher has to be ready to work in a constantly changing teaching/learning environment, be able to realise the newest interdisciplinary didactics principles, to use information communication technologies.

In the presented analysis according to one lesson example, were revealed Natural science and Mathematics relation realisation didactic possibilities. An example scenario "Fruit juice research" was presented. Structural parts of the lesson were presented: discussion of theoretical material, practical work meaningfulness and explanation of the experiment procedure, the experiment and the task performance, the obtained results and discussion of their meaningfulness will allow Natural science teachers to give a lesson about vitamin $\mathrm{C}$ amount in juice and its significance to human organism, using integration possibilities.

Extra tasks, taken from real environment are likely to make the pupils interested in natural objects, and will show interrelationship of the examined phenomenon.

Note

The research is carried out during implementation of the international project „Materials for Teaching Together: Science and Mathematics Teachers collaborating for better results“. Number of the contract: 539242-LLP-1-2013-1-AT-COMENIUS-CMP/. 


\section{References}

Cibulskaitė, N., Kurienè, A. (2015). Būsimųų gamtos mokslų ir matematikos mokytojų integracinių ryšių taikymo gebèjimų ugdymas (is) [Development of practical intersubject competence application by future teachers of natural science and mathematics]. Pedagogika / Pedagogy, 117 (1), 133-142.

Frykholm, J., Glasson, G. (2005). Connecting science and mathematics instruction: Pedagogical context knowledge for teachers. School Science and Mathematics, 105, 127-141. doi: 10.1111/j.1949-8594.2005.tb18047.x.

Furner, J. M., Kumar, D. D. (2007). The mathematics and science integration argument: A stand for teacher education. Eurasia Journal of Mathematics, Science \& Technology Education, 3 (3), 185-189.

Pradinio ir pagrindinio ugdymo bendrosios programos (2008). Gamtamokslinis ugdymas (5 priedas). Vilnius: ŠAC.

Pradinio ir pagrindinio ugdymo bendrosios programos (2008). Matematinis ugdymas (4 priedas). Vilnius: ŠAC.

Šlekienė, V., Ragulienè, L., Lamanauskas, V. (2015a). Tarpdalykinių ryšių realizavimo didaktinès galimybès: tema Nanotechnologijų pradžia - fulerenai [Interdisciplinary relation realisation didactic possibilities: Subject Nanotechnology beginning fullerenes]. Gamtamokslinis ugdymas / Natural Science Education, 12 (1), 20-32.

Šlekienè V., Ragulienè L., Lamanauskas V. (2015b). Gamtos mokslų ir matematikos dalykų integravimo galimybės tyrinèjant vandens druskingumą [Natural science and mathematics integration possibilities researching water salinity]. Gamtamokslinis ugdymas bendrojo lavinimo mokykloje / Natural Science Education in a Comprehensive School, 21, 60-67.

Vidurinio ugdymo bendrosios programos (2011). Gamtamokslinis ugdymas. Vilnius: ŠMM.

Received 25 November 2015; Accepted 16 December 2015

\section{[ $\quad$ Violeta Šlekienè}

PhD., Senior Researcher, Natural Science Education Research Centre, Siauliai University, P. Visinskio Street 25-119, LT-76351 Siauliai, Lithuania

E-mail: violeta@fm.su.lt

Website: http:/ /www.gutc.su.lt

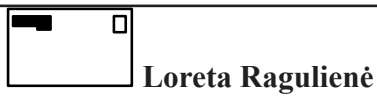

PhD., Senior Researcher, Natural Science Education Research Centre, Siauliai University, P. Visinskio Street 25-119, LT-76351 Siauliai, Lithuania

E-mail: loretar@gmail.com

Website: http:/ /www.gutc.su.lt

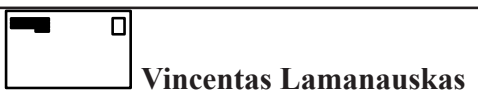

PhD., Professor, Department of Education \& Psychology, University of Šiauliai, Lithuania.

E-mail: v.lamanauskas@ef.su.lt

Website: https://projektas.academia.edu/VincentasLamanauskas 